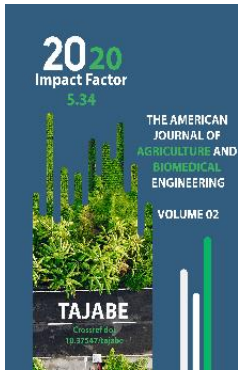

Copyright: Original content from this work may be used under the terms of the creative commons attributes 4.0 licence.

\section{Bioecology Of Melissa Officinalis Plant In Introduction Conditions}

\author{
Sattarov Abdumurod Sattarovich \\ Termez State University, Department Of Botany, Candidate Of Biological Sciences, Associate \\ Professor, Uzbekistan
}

Begmatov Abdusamat Mamatkulovich.

Termez State University, Head Of The Department Of Botany, Candidate Of Biological Sciences, Associate Professor, Uzbekistan

\title{
ABSTRACT
}

Morphological features of melissa officinalis, flowering dynamics, attitude to environmental factors have been studied in the conditions of Termez city of the surkhandarya region. Melissa officinalis in the conditions of introduction was recommended for cultivation in the conditions of introduction, taking into account the ability to multiply from seed, its resistance to high and low temperatures, its non-harmfulness with diseases and pests.

\section{KEYWORDS}

Melissa officinalis, efirmoyl plant, introduction, flower, flowering dyna.

\section{INTRODUCTION}

There are 10-12 thousand species of medicinal plants on earth. The chemical, pharmacological and medicinal properties of more than 1000 plant species have been investigated. There are 577 species of medicinal plants in Uzbekistan.
Currently, 250 types of these are used in scientific medicine.

Since Dorivor is a biologically active substance in the composition of the product of therapeutic importance in the treatment of diseases, it is used in medicine and in 
pharmacy. Medicinal biologically active chemical compounds of therapeutic importance of the plant are called the main causative agents.

In the flora of Uzbekistan 593 species of plants with efirmoy have been identified, they belong to 261 categories and 56 plant families. Of the plants in the conditions of Uzbekistan, 119 species in the 57 category of plantations, 88 species in the 29 category of mint, 65 species in the 26 category of Nettle, 46 species in the 22 category of carnations, 35 species in the 15 category of roses, 29 species in the 7 category of onions, 24 species in the 10 category of

In the surkhandarya region there are 310 species, 165 categories and 54 families of wildgrowing efir oil plants [6]. Among them are the following types of new efirium oil plants: Agrimonia asiatica, crataegus pontica, rezeda bucharica, geranium collinum, prangos bucharica, bunium capusii, ferula kelifi, ajuga turkestanika, eremostachus hissarica, scutellaria bucharica, artemisia kochiiformi, policaria gnaphaledes, pseudohandelia umbellifera, eremurus olgae, Tulipa orithyodes, asparagus bucharica, Iris Sogdiana and others. It turns out that in the Surkhandarya region there are still more than 40 species of promising efir oil plants that are worth studying. Among them are many species that have economic significance. It can also be cited as an example of families of mint, cumin and gooseberry, which are rich in efir oils [5].

\section{MATERIALS AND METHODS}

Currently, the reserves of medicinal plants, which grow naturally, are decreasing under the influence of humans. In order to replace it and meet the needs of our people, it is desirable to increase the variety of medicinal plants and plant them in irrigated regions taking into account the soil and climatic conditions of
Uzbekistan. The moment when the Efir oil becomes high-quality and impressive is due to the budding and flowering period of most plants [2]. At such a time, the upper land masses of the plant should be collected and taken care of. When the buds and flowers are fully mature and the seed fruits are fully ripened, the stem, rhizome, node and onions are harvested at the end of the plant growth period, that is, before the plant goes to sleep $[3,4]$.

In the conditions of the city of Termez, melissa officinalis was taken care of as a landscape plant on irrigated soil. In one bush plant, 30-40 pieces of flowers were formed. The upper part of the land of the plant grows in the Earth's slopes. Tiradi move the leaves and flowers of different colors characteristic of the landscape. On the tip of the generative Branch, 3 pieces are sometimes formed 4 pieces of flowers. It takes 10-15 days until the buds are fully formed. The length of the buds also reaches from 0,2 $\mathrm{CM}$ to $2 \mathrm{~cm}$ in accordance with the maturation times. In the team of Melissa officinalis plant, the red and yellow gultojibergs are extinguished.

\section{RESULTS AND DISCUSSIONS}

Flowering biology. According to the methodology, The Daily flowering of melissa officinalis was studied, and on the scale of the bush, roses were selected. On the scale of the Rose, the number of flowers opened per day was calculated. To do this, The opened flowers on the heels (carp) were removed. According to the results of the study, the opening of flowers in shingles began at 8 o'clock. At this time, the opening of $1 \%$ Flowers was determined. At 10 o'clock, the most abundant opening of flowers was recorded (37 pieces). The air temperature was $23^{\circ} \mathrm{C}$, the relative humidity of the air was $68 \%$. 
The American Journal of Agriculture and Boimedical Engineering (ISSN - 2689-1018)

Published: October 31, 2020 | Pages: 69-73

Doi: https://doi.org/10.37547/tajabe/Volume02Issue10-12

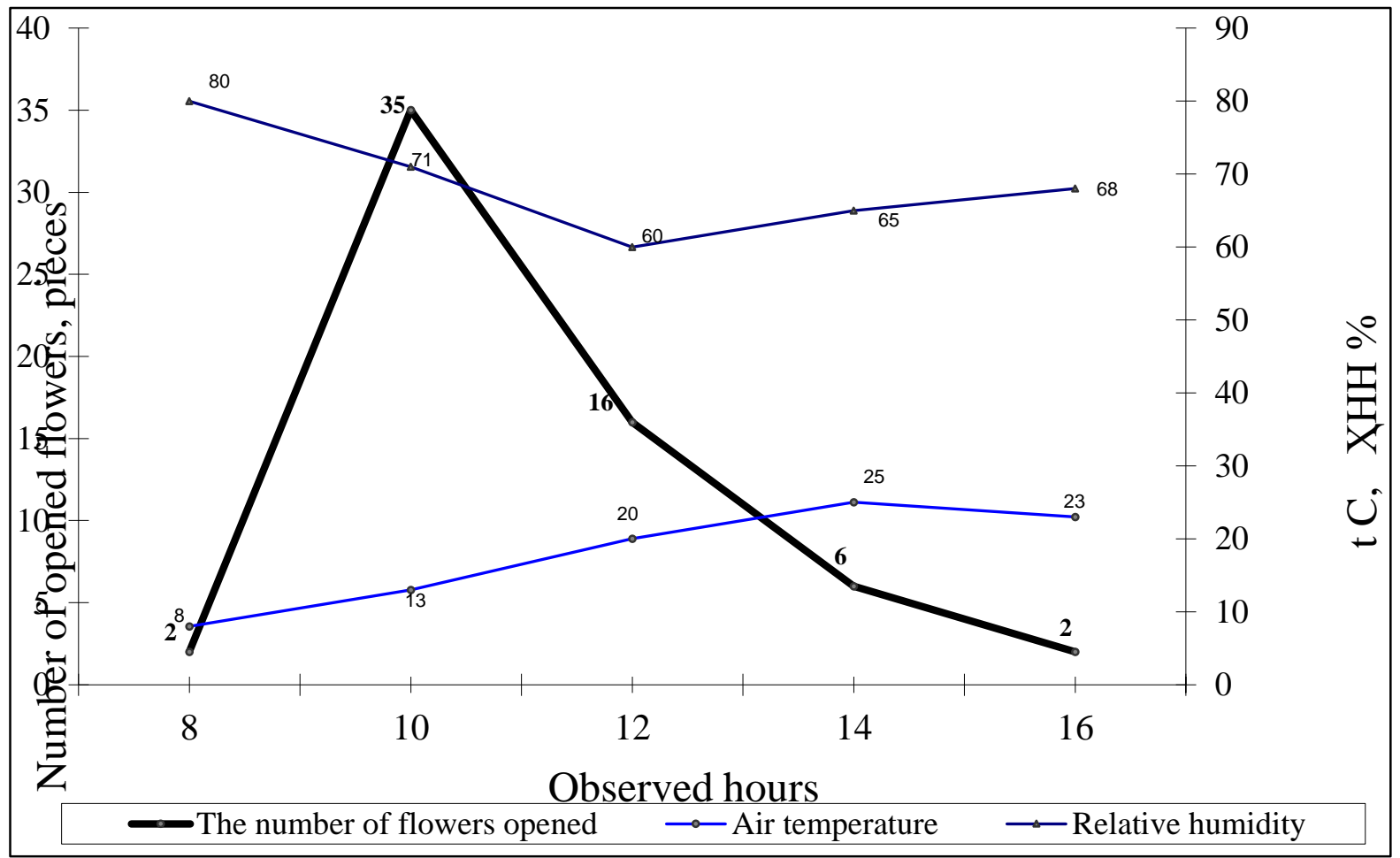

At 16 O'clock, the opening of the flowers decreased. At this time, 2 pieces of flowers were opened.

On the 30 day of May there was a flowering of the Yappa (gross). On June 5, it was determined that the flowering period would decrease. The phertility of the powder grain was studied by staining it with acetocarmin paint. According to the results of the study, the ferthiness of the powder grain of Lemonade was $95 \%$. 


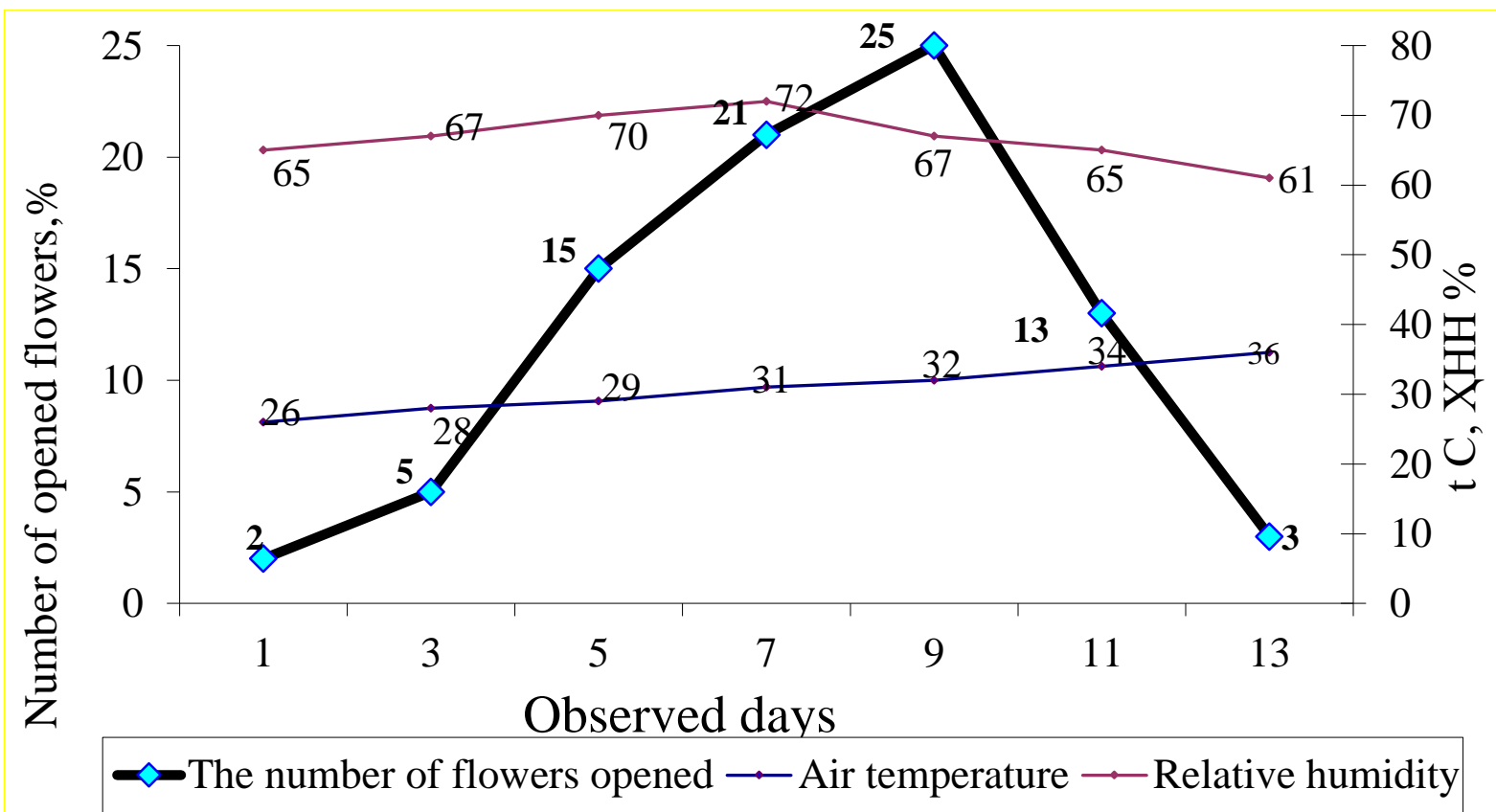

\section{Seedbiology of Melissa officinalis.}

The plant of lemonade is observed until the low temperature of the autumn season is observed. In June, plant seeds grown on the farmyard were harvested. For different periods of time, the seeds were stored in paper bags under room conditions and their fertility was determined. In August, it was planted in a petri dish in conditions of seed storage for a period of 1 month. According to the results of the study, the seed yield was $94 \%$. In seeds stored for two months, however, this indicator was $89 \%$ and in three months it gained $84 \%$ fertility. So it was confirmed that the fertility indicators in the seeds of the Melissaofficinalis plant are much higher.

Attitude to environmental factors and introductory assessment.

The success of plant introduction is assessed by the sum of its characteristics, the most important of which is the completeness of the transition of large (ontogenetic) and small (seasonal) life

cycles of the plant, which is characterized by the preservation of

plant habit. In assessing the success of the introduction, generative development, vegetative reproduction, maintenance of habitus, infestation with disease and pests, plant viability at unfavorable times of the year are taken into account [7]. A 6-point assessment was used to analyze the introduction results of Melissa officinalis. The evaluation of the species was performed on a 100-point scale. The sum of scores between 20-39 was considered unpromising, 4059 - low-prospective, 60-79 - promising and 80-100 - very promising. The ability of Melissa officinalis to produce abundant leaf mass under the conditions of introduction is one of the main indicators of its economic value. Melissa officinalis was not infested with disease and pests under the conditions of introduction. 
Melissa officinalis can also be propagated in field conditions in terms of its ability to reproduce from seed, productivity in relation to high temperatures, disease resistance.

\section{CONCLUSION}

1. In Surkhandarya region Melissa officinalis undergoes all stages of ontogeny. The effect of temperature affected the timing of the onset of vegetation. Due to the onset and duration of budding, flowering and fruiting are observed simultaneously on the scale of the bush.

2. The opening of the flowers of Melissa officinalis was observed from 8 to 16 o'clock. The maximum opening of the flowers, i.e. the peak, was detected at 10 p.m. At this time, the air temperature was $13^{\circ} \mathrm{C}$ and the relative humidity was $71 \%$.

\section{REFERENCE}

1. Ashurmetov A. A., Durdaev B. E. History, problems and prospects of Dorivor plants introduction // plants introduction: problems and prospects: materials of the Republican scientific conference.- Xive: XME, 2003. What? 12-15.

2. Begmatov a.m. Bioecological features of Stevia rebaudiana Bertoni during introduction in the Surkhandarya region. Dis. ... Cand. Biol. Sciences. - Tashkent: an RUz. 2012. - P. 20.

3. Begmatov a.m., rakhmatova M. U. Bioecological features of Glycyrrhiza L.//Modern scientific research and development, No. 3 (20). Moscow, 2018. -Pp. 110-113.

4. Begmatov A.M., Sharipov A.E., Rakhmatova M.He Bioecological features of Stevia rebianaiana Bertoni in the conditions of the surkhandarya region/ / integration of fundamental science and practice: problems and prospects materials of the Republican scientific-practical conference. - Tashkent, 2018.

a. What? 156-157.

5. DjumaevX. Q., Zenkevich I.G., Begmatov A.M., Sattarov A.S. Composition of essential oils of sage salvia sclarea $L$. and their changes depending on the vegetative phases of development. Scientific Bulletin of Namangan State University, 2019. №6. -P. 183-193.

6. Kholmatov Kh., Akhmedov He Or She.A. Farmacognosia. - Tashkent: Abu Ali Ibn Sino, 2007. - b. 269.

7. Sherqulova J.P., Mustafaev I.M., Iminova M.M., Sattarov A.S. Species, host range and geographical distribution of microfungi (dothideomycetes) on introduced trees and shrubs in southern Uzbekistan. Iranian journal of botany, 25 (1), 2019. DQI; 10.22092. ijb.2019.115956.1187. -P. 72-77. 